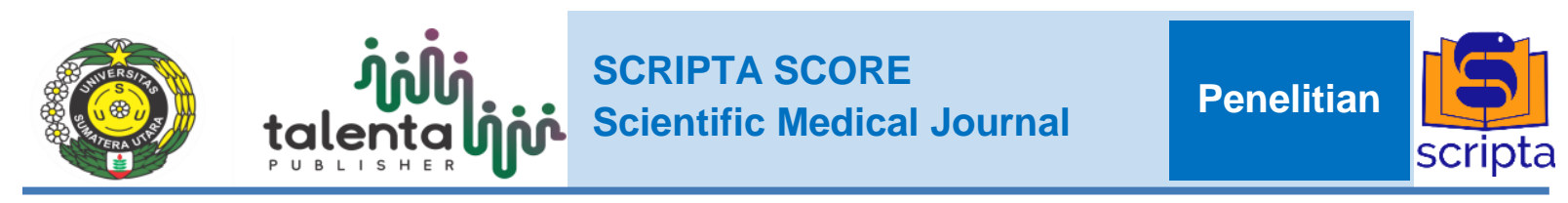

\title{
Hubungan Kesepian dengan Masalah Psikologis dan Gejala Gangguan
}

\author{
Somatis pada Remaja \\ Hafizah Khairi Dafnaz ${ }^{1}$, Elmeida Effendy ${ }^{1}$ \\ ${ }^{1}$ Departemen Kedokteran Jiwa, Fakultas Kedokteran, Universitas Sumatera Utara, Medan
}

\begin{abstract}
ABSTRAK
Latar Belakang: Kesepian menjadi salah satu masalah psikologis yang sering muncul pada remaja. Salah satu penyebab timbulnya kesepian pada remaja adalah tidak terpenuhinya kebutuhan emosi dan sosial. Intensitas kesepian bisa berbeda-beda, ada yang dapat segera melalui perasaan kesepian, namun ada juga yang terus-menerus merasakan kesepian. Hal ini dapat mempengaruhi remaja secara mental, sehingga sering dikaitkan dengan masalah psikologis dan kesehatan somatis. Tujuan: Penelitian ini bertujuan untuk mengetahui hubungan kesepian dengan masalah psikologis dan gejala gangguan somatis pada remaja. Metode: Penelitian ini merupakan studi penelitian analitik dengan desain penelitian cross sectional menggunakan data primer yang berasal dari kuisioner. Sampel penelitian dipilih dengan metode stratified random sampling dari seluruh data kuisioner yang memenuhi kriteria penelitian. Hasil: Pada analisis korelasi Spearman didapatkan nilai p sebesar 0,001 $(\mathrm{p}<0,05)$ yang menunjukkan terdapat hubungan antara kesepian dengan masalah psikologis dan gejala gangguan somatis pada remaja. Analisis bivariat kesepian dengan depresi didapatkan nilai koefisien korelasi $r=0,548$, kesepian dengan kecemasan $r=0,515$, kesepian dengan stres $r=0,472$ dan kesepian dengan gejala gangguan somatis $r=0,528$. Kesimpulan: Terdapat hubungan yang bermakna antara kesepian dengan masalah psikologis dan gejala gangguan somatis pada remaja.
\end{abstract}

Kata kunci: gejala gangguan somatis, kesepian, masalah psikologis

\begin{abstract}
Background: Loneliness is a psychological problem that often arises in adolescents. One of the causes is unfulfilled emotional and social needs. The intensity of loneliness can vary, there can be immediately through a feeling of loneliness, but there are also those who constantly feel lonely. It can affect adolescents mentally, so it is often associated with psychological problems and somatic health. Objectives: This study aimed to know the relationship of loneliness with psychological problems and symptoms of somatic disorders in adolescents. Methods: This study is an analytical study with a cross-sectional design, data that used is primary data from questionnaires. The sample was selected by using the stratified random sampling method from all questionnaire data. Results: In the Spearman correlation analysis, the p-value was $0.001(p<0.005)$ which showed that there was a relationship between loneliness and psychological problems and symptoms of somatic disorders in adolescents. Bivariate analysis between loneliness and depression obtained correlation coefficient $r=0.548$, loneliness and anxiety $r=0.515$, loneliness and stress $r=0.472$ and loneliness and symptoms of somatic disorders $r=0.528$. Conclusion: There was a significant relationship between loneliness and psychological problems and symptoms of somatic disorders in adolescents.
\end{abstract}

Keywords: loneliness, psychological problems, symptoms of somatic disorders Received [31 Dec 2019] | Revised [1 Jun 2020] | Accepted [3 Jun 2020]

\section{PENDAHULUAN}

Kesepian merupakan salah satu masalah psikologis yang tidak dapat dipisahkan dalam kehidupan manusia.
Setiap manusia pernah menghadapi situasi yang dapat menyebabkan kesepian, baik orang dewasa maupun remaja.

Masa remaja adalah masa peralihan dari masa kanak-kanak ke masa dewasa 
yang meliputi perubahan biologis, perubahan psikologis, dan perubahan sosial. ${ }^{[1]}$ Perubahan psikososial pada remaja dibagi dalam tiga tahap yaitu remaja awal (early adolescent) yang terjadi pada usia usia 12-14 tahun, pertengahan (middle adolescent) terjadi antara usia 15-17 tahun, dan akhir (late adolescent) dimulai pada usia 18 tahun. ${ }^{[2]}$

Kesepian remaja telah dikaitkan dengan perubahan sosial dan perkembangan yang terjadi saat ini. Secara khusus, meningkatnya kebutuhan akan otonomi terhadap diri sendiri dan keinginan untuk membangun identitas remaja di luar dari lingkungan keluarga terlihat dengan adanya upaya untuk memisahkan diri dari orang tua dan upaya untuk membangun hubungan baru dengan teman sebaya di dunia sosial yang lebih luas. Namun, harapan yang tidak sesuai dan tidak tercapai, merasa ditolak, kegagalan dalam membuat peran sosial, serta penolakan dari orang tua, semuanya dapat mengakibatkan perasaan kesepian. ${ }^{[3]}$

Penelitian telah menunjukkan bahwa perasaan kesepian bisa memprediksi gejala depresi. $^{[4]}$ Gangguan saat tidur dan meningkatkan resistensi pembuluh darah ${ }^{[5]}$ dan gangguan kesehatan mental dan kognisi. ${ }^{[6]}$ Di tingkat sel bisa menyebabkan peningkatan tekanan darah sistolik $^{[7]}$, kurangnya ekspresi gen yang mengandung elemen respon glukokortikoid antiinflamasi (GREs), ekspresi berlebih dari gen yang membawa elemen respons untuk transkripsi faktor proinflamasi NF$\mathrm{B} / \operatorname{Rel}^{[8]}$, dan perubahan imunitas. ${ }^{[9]}$

Kesepian bisa disebabkan karena individu tersebut kurang mampu membangun keterbukaan dengan orang lain sehingga dia tumbuh menjadi orang yang keterampilan sosialnya terganggu lalu menimbulkan perasaan takut dan cemas. $^{[10]}$ Penelitian lain didapatkan bahwa kecemasan atau ansietas merupakan bentuk gangguan psikologi yang cukup banyak ditemukan pada remaja di Pekanbaru $(65,2 \%)$. Penelitian yang dilakukan pada pelajar salah satu
SMA Negeri di Surakarta juga menunjukkan hasil yang sama yaitu sebanyak $60 \%$ responden mengalami gangguan kecemasan atau ansietas. ${ }^{[11]}$

Somatisasi didefinisikan sebagai suatu proses dimana distres dianggap sebagai suatu gejala fisik. Somatisasi adalah hasil dari respon fisiologis yang mempengaruhi manifestasi dari gejala fisik, yang mungkin sering melibatkan faktor psikologis. ${ }^{[12]}$ Paling sering gejala somatis bersifat sementara dan sembuh dengan sedikit atau tanpa intervensi. Namun, somatisasi dapat bertahan, terutama ketika ada faktor predisposisi atau yang mempengaruhi presentasi gejala lanjutan. ${ }^{[13]}$

Berdasarkan keterangan di atas, keadaan kesepian yang dialami remaja merupakan keadaan mental yang tidak baik sehingga kesepian yang dialami oleh remaja dapat melatarbelakangi adanya permasalahan psikologis dan gangguan somatis. Penelitian ini dilakukan untuk mengetahui apakah ada hubungan antara kesepian dengan masalah psikologis dan somatis pada remaja.

\section{METODE}

\section{Desain dan Sampel Penelitian}

Penelitian ini adalah penelitian analitik dengan desain cross sectional yang dilaksanakan di Sekolah Menengah Atas (SMA) Negeri 2 Binjai. Waktu penelitian dilakukan pada bulan Agustus hingga September 2019. Populasi dalam penelitian ini adalah siswa-siswi di Sekolah Menengah Atas (SMA) Negeri 2 Binjai. Teknik pengambilan sampel adalah stratified random sampling yang terdiri atas siswa-siswi SMA Negeri 2 Binjai kelas X, XI, dan XII yang memenuhi kriteria penelitian dengan penentuan besar sampel analisis korelatif. Jenis data yang digunakan adalah data primer yang diperoleh langsung dari sampel penelitian dengan mengisi beberapa kuisioner. 


\section{Instrumen Penelitian}

1. Kuisioner UCLA (University of California Los Angeles) Loneliness Scale 3 adalah instrumen yang digunakan untuk mengukur tingkat kesepian. Alat ukur UCLA juga telah digunakan sebagai alat ukur pada penelitian yang dilakukan oleh Wijaya pada tahun 2018 untuk mengukur kesepian pada pengguna instagram Indonesia.

2. Kuisioner DASS 42 (Depression, Anxietas, Stress Scale 42) adalah seperangkat skala subjektif yang digunakan untuk menilai status emosional negatif dari depresi, kecemasan, stres. Alat ukur DASS 42 juga telah digunakan sebagai alat ukur pada penelitian yang dilakukan oleh Masdar pada tahun 2016 untuk mengukur depresi, ansietas dan stres pada remaja. ${ }^{[11]}$

3. Kuisioner SOMS (Screening For Somatization Symptom) adalah instrumen yang terdiri dari 53 gejala tubuh yang respon jawabannya mengindikasikan hadir atau tidaknya gejala selama dua tahun belakangan. Kuesioner ini telah diuji validitas dan reliabilitas di Indonesia. Penerjemahan menggunakan metode back and forward translation dengan bantuan 2 ahli bahasa.

Data yang diperoleh dari penelitian ini kemudian dikumpulkan dan dianalisa dengan analisis korelasi.

\section{HASIL}

Tabel 1 menunjukkan karakteristik sampel yang diteliti yaitu jenis kelamin, usia, kesepian, depresi, kecemasan, stres dan gejala gangguan somatis. Total 99 responden yang terlibat dalam penelitian ini, yang mana didapatkan persentase jenis kelamin laki-laki sebesar 39,4\% sedangkan perempuan $60,6 \%$. Persentase umur tertinggi responden adalah umur 15 tahun sebesar 33,3\%. Lebih dari separuh responden mengalami kesepian dengan prevalensi tertinggi pada tingkat ringan sebesar 64,6\%, depresi normal 44,4\%, kecemasan normal $26,2 \%$, stres normal $43,4 \%$ dan gejala gangguan somatis sangat rendah $48,5 \%$.

Tabel 1. Distribusi Frekuensi

\begin{tabular}{|c|c|c|}
\hline Variabel & $\mathrm{N}=99$ & $\%$ \\
\hline \multicolumn{3}{|l|}{ Jenis Kelamin } \\
\hline Laki-laki & 39 & 39,4 \\
\hline Perempuan & 60 & 60,6 \\
\hline \multicolumn{3}{|l|}{ Umur (tahun) } \\
\hline 14 & 17 & 17,2 \\
\hline 15 & 33 & 33,3 \\
\hline 16 & 24 & 24,2 \\
\hline 17 & 23 & 23,2 \\
\hline 18 & 2 & 2 \\
\hline \multicolumn{3}{|l|}{ Kesepian } \\
\hline Normal & 10 & 10,1 \\
\hline Ringan & 64 & 64,6 \\
\hline Sedang & 25 & 25,3 \\
\hline Berat & 0 & 0 \\
\hline \multicolumn{3}{|l|}{ Depresi } \\
\hline Normal & 44 & 44,4 \\
\hline Ringan & 16 & 16,2 \\
\hline Sedang & 20 & 20,2 \\
\hline Berat & 16 & 16,2 \\
\hline Sangat Berat & 3 & 3 \\
\hline \multicolumn{3}{|l|}{ Kecemasan } \\
\hline Normal & 26 & 26,2 \\
\hline Ringan & 10 & 10,1 \\
\hline Sedang & 24 & 24,3 \\
\hline Berat & 21 & 21,2 \\
\hline Sangat Berat & 18 & 18,2 \\
\hline \multicolumn{3}{|l|}{ Stres } \\
\hline Normal & 43 & 43,4 \\
\hline Ringan & 15 & 15,2 \\
\hline Sedang & 27 & 27,3 \\
\hline Berat & 10 & 10,1 \\
\hline Sangat Berat & 4 & 4 \\
\hline \multicolumn{3}{|c|}{ Gejala Gangguan Somatis } \\
\hline Sangat Rendah & 48 & 48,5 \\
\hline Rendah & 42 & 42,4 \\
\hline Tinggi & 9 & 9,1 \\
\hline Sangat Tinggi & 0 & 0 \\
\hline
\end{tabular}


Analisis hubungan kesepian dengan masalah psikologis dan gejala gangguan somatis pada penelitian ini diawali dengan uji normalitas terlebih dahulu. Setelah menggunakan uji normalitas KolmogorovSmirnov didapatkan data tidak terdistribusi normal (nilai $\mathrm{p}=0,001$ ) sehingga uji korelasi yang dipakai adalah Spearman.

Tabel 2. Analisis Korelasi

\begin{tabular}{lccccccccc}
\hline & Depresi & \multicolumn{2}{c}{ Kecemasan } & & Stres & \multicolumn{3}{c}{$\begin{array}{c}\text { Gejala } \\
\text { Gangguan } \\
\text { Somatis }\end{array}$} \\
\cline { 2 - 10 } & $\boldsymbol{p}$ & $\boldsymbol{r}$ & $\boldsymbol{p}$ & $\boldsymbol{r}$ & $\boldsymbol{p}$ & $\boldsymbol{r}$ & $\boldsymbol{p}$ & $\boldsymbol{r}$ \\
\hline Kesepian & $0,001^{*}$ & 0,548 & $0,001^{*}$ & 0,515 & $0,001^{*}$ & 0,472 & $0,001^{*}$ & 0,528 \\
\hline
\end{tabular}

\section{PEMBAHASAN}

Berdasarkan tabel 2 menunjukkan bahwa dari uji korelasi didapatkan nilai $\mathrm{p}$ sebesar 0,001 $(<0,05)$ yang berarti ada hubungan antara kesepian dengan depresi pada remaja. Koefisien korelasi (r) didapatkan sebesar 0,548 (korelasi sedang). Koefisien korelasi tersebut menunjukkan terdapat korelasi sedang antara kesepian dengan depresi. Arah korelasi adalah positif artinya semakin tinggi nilai kesepian maka nilai depresi juga meningkat.

Depresi merupakan gangguan emosional atau suasana hati yang buruk yang ditandai dengan kesedihan yang sangat lama, merasa tidak berarti, perasaan bersalah dan putus harapan minimal dalam kurun waktu dua minggu. Seluruh proses mental yang meliputi proses berpikir, berperasaan, dan berperilaku tersebut akhirnya akan mempengaruhi motivasi untuk seseorang melakukan aktivitasnya sehari-hari maupun pada hubungan intrapersonal. ${ }^{[14]}$

Depresi merupakan respon yang normal terhadap pengalaman hidup yang negatif, misalnya kehilangan anggota keluarga, kehilangan harta benda, status sosial dan sebagainya. Banyak hal yang menyebabkan terjadinya depresi pada seseorang, salah satunya adalah faktor sosial. Faktor sosial disini seperti adanya peristiwa hidup yang negatif seperti kehilangan anggota keluarga dan berharap secara berlebihan kepada orang tua dan teman sebaya. Rasa berharap ini muncul karena biasanya individu tersebut tidak memiliki hubungan sosial yang baik dengan keluarga maupun lingkungan sosialnya sehingga timbul rasa kesepian dalam diri individu tersebut. Kesepian dapat didefinisikan sebagai sebuah kondisi dimana keadaan mental dan emosional individu tersebut merasa kurang dan merasa tidak puas dengan hubungan yang dimiliki oleh dirinya dan orang lain sehingga terjadi kesenjangan antara hubungan sosial dimiliki dengan hubungan sosial yang diinginkan oleh individu tersebut.

Tabel 2 juga menunjukkan bahwa dari uji korelasi didapatkan nilai $\mathrm{p}$ sebesar $0,001 \quad(<0,05)$ yang berarti ada hubungan antara kesepian dengan kecemasan pada remaja. Koefisien korelasi (r) didapatkan sebesar 0,515 . Kesepian bisa disebabkan karena individu tersebut kurang mampu membangun keterbukaan dengan orang lain sehingga dia tumbuh menjadi orang yang keterampilan sosialnya terganggu lalu menimbulkan perasaan takut dan cemas. ${ }^{[15]}$ Penelitian lain didapatkan bahwa kecemasan atau ansietas merupakan bentuk gangguan psikologi yang cukup banyak ditemukan pada remaja di Pekanbaru (65,2\%). Penelitian yang dilakukan pada pelajar salah satu SMA Negeri di Surakarta juga menunjukkan hasil yang sama yaitu sebanyak $60 \%$ responden mengalami gangguan kecemasan atau ansietas. ${ }^{[11]}$

Meskipun kesepian berhubungan dengan banyak faktor risiko dan masalah kesehatan, kecemasan sosial tampaknya 
sangat relevan dengan kesepian. Gangguan kecemasan sosial adalah gangguan psikologis yang ditandai oleh ketakutan akan evaluasi negatif oleh orang lain. ${ }^{[16]}$ Individu dengan kecemasan ini memiliki keyakinan negatif tentang diri mereka sendiri dan dunia dan terlibat dalam perilaku penghindaran, yang membatasi peluang mereka untuk terlibat dalam hubungan sosial yang bermakna.

Tabel 2 menunjukkan bahwa dari uji korelasi didapatkan nilai $\mathrm{p}$ sebesar 0,001 $(<0,05)$ yang berarti ada hubungan antara kesepian dengan stres pada remaja. Koefisien korelasi (r) didapatkan sebesar 0,472. Penyebab stres pada remaja dapat dipicu dari kematian orang yang dicintai atau menyaksikan peristiwa yang traumatis, penyebab yang paling umum berhubungan dengan sekolah seperti intimidasi dari teman-teman, masalah dengan guru, dan kesulitan akademis dan hubungan interpersonal seperti konflik dengan orang tua, saudara, dan teman sebaya. ${ }^{[11]}$

Setiap orang yang mengalami ataupun terpapar stresor yang cukup besar belum tentu merasakan efek stres dalam bentuk gangguan psikologis yang sama. Hal tersebut dapat terjadi oleh karena berbedanya sumber-sumber penanggulangan stres setiap individu, seperti dukungan dari lingkungan sosial (dukungan keluarga, teman, masyarakat dan lingkungan komunitas) individu tersebut. ${ }^{[17]}$

Berdasarkan hasil kuisioner UCLA, terdapat hasil yang bervariasi pada tingkat kesepian pada remaja. Kesepian muncul karena ada kesenjangan antara apa yang diinginkan dan yang diperoleh dari suatu hubungan tertentu. Tingkat kesepian yang dirasakan seseorang dipengaruhi oleh jaringan sosial (misalnya kualitas hubungan dengan teman, keluarga ataupun tetangga), standar hubungan (tujuan yang ingin dicapai dalam suatu hubungan), serta karakteristik pribadi (misalnya keterampilan sosial, percaya diri, ataupun kecemasan). Kesepian merupakan hal yang bersifat pribadi dan akan ditanggapi berbeda oleh setiap orang, bagi sebagian orang kesepian merupakan yang bisa diterima secara normal, namun bagi sebagian orang kesepian bisa menjadi sebuah kesedihan yang mendalam. ${ }^{[18]}$

Hasil dari penelitian ini mengindikasikan adanya hubungan antara kesepian dengan masalah psikologis pada remaja, dimana semakin tinggi tingkat kesepian seseorang maka akan semakin tinggi masalah psikologisnya. Kesepian dapat terjadi karena hubungan yang diharapkan individu mengalami perubahan, namun pada kenyataannya hubungan tersebut tidak terjadi perubahan. Seperti dengan bertambahnya usia tentu ada keinginan akan perubahan dalam hubungan, ketika hal tersebut tidak terjadi maka dapat menyebabkan kesepian.

Seseorang yang mengalami kesepian cenderung memiliki self-esteem yang rendah, memiliki sikap yang negatif kepada orang lain dan kurang dalam kemampuan sosial. Perilaku interpersonal yang pasif dan tidak responsif dapat menganggu dan menjengkelkan bagi orang lain sehingga munculkan penolakan sosial yang dapat membuat kesepian semakin bertambah buruk sehingga menyebabkan kesehatan fisik dan mental mengalami penekanan. Dimana pada penelitian lain menunjukkan bahwa kuantitas dan kualitas kontak jaringan sosial berimbas pada kesehatan. ${ }^{[19]}$

Dari tabel 2 didapatkan bahwa ada hubungan antara kesepian dengan gejala gangguan somatis pada remaja. Koefisien korelasi (r) didapatkan sebesar 0,528. Koefisien korelasi tersebut menunjukkan terdapat korelasi sedang antara kesepian dengan gejala gangguan somatis pada remaja.

Penelitian lain menunjukkan bahwa kelelahan merupakan gejala psikosomatik yang paling sering dialami oleh remaja di Hungaria, selain itu juga diikuti dengan masalah tidur dan sakit punggung (bagian bawah). Selain itu terdapat masalah dengan hubungan sosial seperti kebutuhan interaksi sosial yang belum terpenuhi, 
daya saing antar individu dan rasa malu sehingga menyebabkan keluhan psikosomatis. $^{[20]}$

Stresor kehidupan merupakan pengalaman yang dialami dalam keseharian individu. Stres dapat menjadi konstruktif jika didukung oleh kualitas kepribadian yang optimal. Sebaliknya stresor kehidupan dapat memunculkan gangguan somatisasi jika individu memiliki kualitas kepribadian yang tidak optimal. Jika kualitas dari aspekaspek kepribadiannya kurang optimal maka individu tersebut akan rentan mengalami gangguan somatis dan begitu juga sebaliknya apabila individu tersebut mempunyai kualitas yang optimal dari aspek-aspek tersebut maka peristiwaperistiwa yang menekan atau mendapati suatu stresor, meskipun sering muncul di kesehariannya dapat dimaknai sebagai sebuah tantangan atau sebuah hambatan yang bisa diyakini akan bisa diatasinya. Oleh karena itu stresor kehidupan tidak selalu memunculkan gejala patologis berupa gangguan somatisasi. ${ }^{[21]}$

Dari hasil penelitian ini walaupun terdapat korelasi yang bermakna antara kesepian dengan gejala gangguan somatis pada remaja namun hanya sedikit yang melaporkan mengalami gangguan somatis. Hal ini bisa saja terjadi karena ada faktorfaktor lain yang bisa mempengaruhi seseorang merasakan gangguan somatis atau tidak. Salah satunya adalah kepribadian. Kepribadian memengaruhi timbulnya gangguan somatis pada seseorang karena bisa berperan sebagai tameng atau pelindung terhadap gangguan somatis. Beberapa aspek kepribadian yang dinilai adalah harga diri, kemandirian dan kepribadian tahan banting (hardness personality) yang mana berperan dalam menghadapi suatu stresor. ${ }^{[19]}$

Jika kualitas dari aspek-aspek kepribadiannya kurang optimal maka individu tersebut akan rentan mengalami gangguan somatis dan begitu juga sebaliknya apabila individu tersebut mempunyai kualitas yang optimal dari aspek-aspek tersebut maka peristiwa- peristiwa yang menekan atau mendapati suatu stresor, meskipun sering muncul di kesehariannya dapat dimaknai sebagai sebuah tantangan atau sebuah hambatan yang bisa diyakini akan bisa diatasinya. Oleh karena itu, stresor kehidupan tidak selalu memunculkan gejala patologis berupa gangguan somatisasi.

Penelitian ini dilakukan dengan pengisian angket instrumen yang dilakukan oleh peneliti dan bersama-sama dengan responden sehingga diperoleh data yang lebih akurat. Namun, penelitian ini memiliki keterbatasan yang bisa mempengaruhi hasil penelitian. Pertama, penelitian ini tidak meneliti variabel selain kesepian yang juga berperan dalam menimbulkan masalah psikologis dan gejala gangguan somatis. Kedua, terdapat kemungkinan responden menandai begitu saja salah satu pilihan sekadar memenuhi permintaan peneliti untuk mengisi kuesioner tersebut tanpa memikirkan benar-benar apakah jawaban itu sesuai atau tidak dengan pendiriannya.

\section{KESIMPULAN}

Pada penelitian ini terdapat hubungan yang bermakna antara kesepian dengan masalah psikologis dan gejala gangguan somatis pada remaja.

\section{SARAN}

Berdasarkan penelitian yang telah dilakukan, saran yang dapat disampaikan adalah:

1. Peneliti menyarankan kepada para siswa terutama yang terdeteksi mengalami kesepian untuk memperhatikan kualitas dari kesehatan mental sehingga dapat meningkatkan kesejahteraan psikologis terutama dalam aspek hubungan yang positif dengan orang lain dan aspek perkembangan pribadi.

2. Peneliti menyarankan kepada pihak sekolah untuk melengkapi sarana 
dan prasarana bimbingan konseling dan selalu memberikan motivasi kepada peserta didik.

3. Penelitian lebih lanjut dengan kuisioner yang lebih spesifik diperlukan untuk menghubungkan kesepian dengan masalah psikologis dan gejala gangguan somatis.

\section{DAFTAR PUSTAKA}

[1] Palinoan EL. Pengaruh konformitas dengan agresivitas pada kelompok geng motor di Samarinda. eJournal Psikologi. 2015;4(1):79-94.

[2] Batubara JR. Adolescent Development (Perkembangan Remaja). Sari Pediatri. 2010;12(1):21-29.

[3] Stickley A, Koyanagi A, Koposov R, Blatný M, Hrdlička M, SchwabStone M dan Ruchkin V. Loneliness and its association with psychological and somatic health problems among Czech, Russian and U.S. adolescents. BMC Psychiatry. 2016;16:128. doi: $\underline{10.1186 / \mathrm{s} 12888-}$ 016-0829-2

[4] Cacioppo JT, Hughes ME, Waite LJ, Hawkley LC, Thisted RA. Loneliness as a specific risk factor for depressive symptoms: crosssectional and longitudinal analyses. Psychol Aging. 2006;21(1):140-51. doi: $\underline{\text { 10.1037/0882-7974.21.1.140 }}$

[5] Cacioppo JT, Hawkley LC, Crawford LE, Ernst JM, Burleson $\mathrm{MH}$, Kowalewski RB, Malarkey WB, Van Cauter E, Berntson GG. Loneliness and health: potential mechanisms. Psychosom Med. 2002;64(3):407-17. doi: 10.1097/00006842-20020500000005

[6] Wilson RS, Krueger KR, Arnold SE, Schneider JA, Kelly JF, Barnes LL, Tang Y, Bennett DA. Loneliness and risk of Alzheimer disease. Arch Gen Psychiatry. 2007;64(2):234-40. doi: 10.1001/archpsyc.64.2.234
[7] Hawkley LC, Masi CM, Berry JD, Cacioppo JT. Loneliness is a unique predictor of age-related differences in systolic blood pressure. Psychol Aging. 2006;21(1):152-64. doi: 10.1037/0882-7974.21.1.152

[8] Cole SW, Hawkley LC, Arevalo JM, Sung CY, Rose RM, Cacioppo JT. Social regulation of gene expression in human leukocytes. Genome Biol. 2007;8(9):R189. doi: 10.1186/gb2007-8-9-r189

[9] Pressman SD, Cohen S, Miller GE, Barkin A, Rabin BS, Treanor JJ. Loneliness, social network size, and immune response to influenza vaccination in college freshmen. Health Psychol. 2005;24(3):297-306. doi: $10.1037 / 0278-6133.24 .3 .297$

[10] Gainau MB. Keterbukaan diri (self disclosure) siswa dalam perspektif budaya dan implikasinya bagi konseling. Jurnal Penelitian Ilmiah Widya Warta. 2009;33(1):95-112.

[11] Masdar H, Saputri PA, Rosdiana D, Chandra F, Darmawi. Depresi, ansietas, dan stres serta hubungannya dengan obesitas pada remaja. Jurnal Gizi Klinik Indonesia. 2016;12(4):138.

[12] Ibeziako P, Bujoreanu S. Approach to psychosomatic illness in adolescents. Curr Opin Pediatr. 2011;23(4):384-9. doi: 10.1097/MOP.0b013e3283483f1c

[13] Andresen JM, Woolfolk RL, Allen LA, Fragoso MA, Youngerman NL, Patrick-Miller TJ, Gara MA. Physical symptoms and psychosocial correlates of somatization in pediatric primary care. Clin Pediatr. 2011;50(10):904-9. doi: 10.1177/0009922811406717

[14] Dirgayunita A. Depresi: Ciri, Penyebab dan Penangannya. AnNafs. 2016;1(1):1-14.

[15] American Psychiatric Association. Diagnostic and statistical manual of mental disorders: DSM-5. Virginia: American Psychiatric Association; 
2013.

[16] Tirta M., Wirasto RT, Huriyati E. Status stres psikososial dan hubungannya dengan status gizi siswa SMP Stella Duce 1 Yogyakarta. Jurnal Gizi Klinik Indonesia. 2010;6(3):138-44.

[17] Zimmer-Gembeck MJ, Skinner EA. Adolescents coping with stress: development and diversity. School Nurse News. 2010;27(2):23-8.

[18] Piko BF, Varga S, Mellor D. Are adolescents with high self-esteem protected from psychosomatic symptomatology? Eur J Pediatr. 2016;175(6):785-92. doi: 10.1007/s00431-016-2709-7

[19] Hadjam MN. Peranan kepribadian dan stres kehidupan terhadap gangguan somatisasi. Jurnal Psikologi. 2003;30(1):36-56.

[20] Croezen S. Social relationship and healty ageing, epidemiological evidence for development of a local intervention programme. Wageningen: Wageningen University \& Research. 2010.

[21] Aji SS. Stress minor dan gangguan psikosomatis pada ibu rumah tangga tidak bekerja. Yogyakarta: Fakultas Psikologi Universitas Wangsa Manggala. 2001. 